\title{
WILD ORCHID DIVERSITY OF HIGHLAND FOREST IN THE HEART OF BORNEO: LONG BANGA AND TAMA ABU, SARAWAK
}

\author{
Edward E. Besi', Dome Nikong², Runi S. Pungga, Rusea Go ${ }^{1, *}$ \\ ${ }^{1}$ Universiti Putra Malaysia, Malaysia \\ ${ }^{2}$ Kg Sungai Tong, Terengganu, Malaysia \\ ${ }^{3}$ Forest Department Sarawak, Malaysia \\ *e-mail:rusea@upm.edu.my
}

Received: 16.04.2020. Revised: 01.08.2020. Accepted: 16.08.2020.

\begin{abstract}
The Heart of Borneo $(\mathrm{HoB})$ initiative facilitates conservation and environment protection while enhancing sustainable development that safeguards the welfare of natural resources and inhabitants of the island. The HoB research expeditions conducted in the Long Banga and Tama Abu were aimed to document the highland orchid species inhabited in one of the largest remaining transboundary rainforests in the world, which are racing dissolution from their habitat. Thus the resolution for their conservation in situ and ex situ could be drafted meritoriously. The research expeditions in the protected transboundary forest areas revealed a total of 206 species and 59 genera. A total of 118 species of 46 genera were recorded during the HoB Long Banga 2016 expedition, while 117 species in 46 genera were found from the HoB Tama Abu 2017 expedition. Roughly 70\% of the species documented were epiphytes. A few of them were mycoheterotrophs, such as Aphyllorchis pallida, Cystorchis aphylla, and Tropidia saprophytica, and several «jewel» orchids, including Cystorchis stenoglossa and Macodes petola. Astonishingly, we discovered a number of endemic and newly recorded orchid species for Borneo. In Long Banga, the riverine forests are home to a higher number of orchids than the inland forests, owing to the presence of host trees with a spreading crown structure and moist bark texture suited epiphyte colonisation. In addition, the riverine forests are banked by a swampy alluvial vegetation that encourage the terrestrial species to grow in. Sites of the inland forests were seen disturbed with wide canopy gaps lacking of the emergent layer. Contrarily, in Tama Abu, the inland forest perceived as the more preferable habitats for orchids to thrive in as it was an undisturbed forested belt. In addition, they had a higher humidity essential for the orchid growth. It was not surprisingly, that a high abundance of orchid species was encountered in the undisturbed inland hill forest roofed with dense tree canopy cover. The hills transitioned into a montane vegetation with a lower number of species. This parameter peaked in a mossy forest, a distinct habitat harbouring endemic and rare species. In addition, ten endemic species are assessed as EN B2b(iii). Herewith, our discovery infers the need for a continuous biodiversity monitoring and conservation assessment to maintain orchid species survival and to reveal the accurate species richness within the highland habitats of Sarawak. Additionally, underlined herein is the need for establishment of an arboretum or a conservation centre for orchids to accommodate the botanical study.
\end{abstract}

Key words: conservation assessment, endemism, inland forest, Northern Sarawak, Malaysia, Orchidaceae, riverine forest, species composition

\section{Introduction}

Orchids belong to the family Orchidaceae and are considered to be the most fascinating and valuable group of flowering plants advanced in the floral variation and distinctive form among the monocotyledons (Go et al., 2010). Approximately, about 25 000-35 000 of orchid species with 800-1000 genera are distributed throughout the world (Gogoi et al., 2012). Malaysia is well-endowed with orchids. It is estimated that as abundant as 972 species occur in Peninsular Malaysia and 3000 species occur in Borneo (Lamb, 1991; Beaman et al., 2001; Ong et al., 2017). Orchids are adapting to different types of ecosystems, especially in tropical mountainous regions and isolated islands (Hassler \& Rheinheimer, 2013). Some of them adapted to extreme dry conditions such as the semi-desert habitat (Pridgeon, 2014).

Orchids are of conservation objectives due to their research and commercial importance, and in- trinsic aesthetic value within their habitats (FloresPalacios \& Valencia-Diaz, 2007; Cruz-Fernández et al., 2011). Unfortunately, orchids are also quite wellknown among the endangered species. A large number are neglected and may not have been discovered yet because of the loss of habitat resulting from human activities in the Borneo region (Wood \& Cribb, 1994; Edwards et al., 2012; Gaveau et al., 2014). Concentrated on the highland forest of Borneo is one of the world's greatest centres for orchid diversity that grows as epiphytes, terrestrials, mycoheterotrophs, lithophytes or rheophytes (Wood \& Cribb, 1994; Beaman et al., 2001). Also, each mountain range has its own distinctive features that support a wealth of flora and fauna, including orchids (Wood \& Cribb, 1994; Beaman et al., 2001; Majit et al., 2014). It is within the Heart of Borneo (HoB), which is part of the transboundary conservation initiative that spreads across Borneo central highlands forests of Malaysia, Brunei, and Indonesia. The HoB ambitious initiative 
covers an area of $26900 \mathrm{~km}^{2}$ spanning across six administrative divisions and nine districts.

There are lacking records on orchids native to highland forests in Northern Borneo, as the last known data collected from the area was made 124 years ago (Ridley, 1896; Go \& Pungga, 2018). This earliest enumeration of orchids in the northern part was procured by Ridley (1896) based on the collections by Dr. Haviland and Bishop Hose in Sarawak and Mr. Pryer in Sabah, together with other enthusiasts in Singapore. The most recently published botanical survey on orchids of Borneo was done about two years ago in Belaga (Ling \& Sang, 2018), although the area is not a highland, but a low forested hill.

For these reasons, an aspiring conservation programme, «Sarawak Heart of Borneo» that covers not just any area in Borneo, but highland forests at the core or the «heart» of the island was initiated. It is aimed to identify and create an inventory of all orchid species that exist in the mountainous area before they become extinct along with their habitat, and to conserve them in situ and ex situ. To date, a vast majority of diversity and ecological research were focused on the northern parts of Sarawak. However, uncontrollable forest exploitation drove rapid deterioration to the forests of the region, and rescuing them is one of the main objectives of the $\mathrm{HoB}$ conservation programme. This paper is a first demonstration of the orchid diversity, with a focus on highland vegetation in the northeast part of Sarawak, in the Tama Abu range, and the inventory was done through the exploration (Fig. 1).
Also, reported here is our first assessment on the conservation status of the endemic yet endangered orchid species in Borneo. An appraisal of flora biodiversity and their conservation status is an essential step towards the conservation of forest biodiversity.

\section{Material and Methods}

Botanical surveys were carried out in pristine hill to montane forest in the Long Banga and Tama Abu in the Tama Abu Range from 21 August 2016 to 1 September 2016 and from 13 August 2017 to 27 August 2017, respectively. Long Banga and Tama $\mathrm{Abu}$ are located in the Tama Abu range surrounded by Dayak's rural villages located in the northeast of Sarawak, Ulu Baram, in the Marudi division. The geomorphology of Tama Abu range with extension to the Kelabit Highlands in the northeast illustrates «backbone» highlands of Sarawak. However, detailed geological information of this large forest area is deficient. We are deprived of an in-depth description of soil and geomorphological features in the mentioned area. Though there are at least two rock formations similar to Meligan Formation and Kelabit Formation in Kelabit Highlands that probably exist in this area based on previous brief geological reports of Liechti et al. (1960), Haile (1962) and Thomson (2015). Also, referable, a description of the major vegetation types of Pulong Tau National Park was made by Pearce (2006). Therefore, in order to enrich the published information, our observations noted during the expeditions are incorporated.

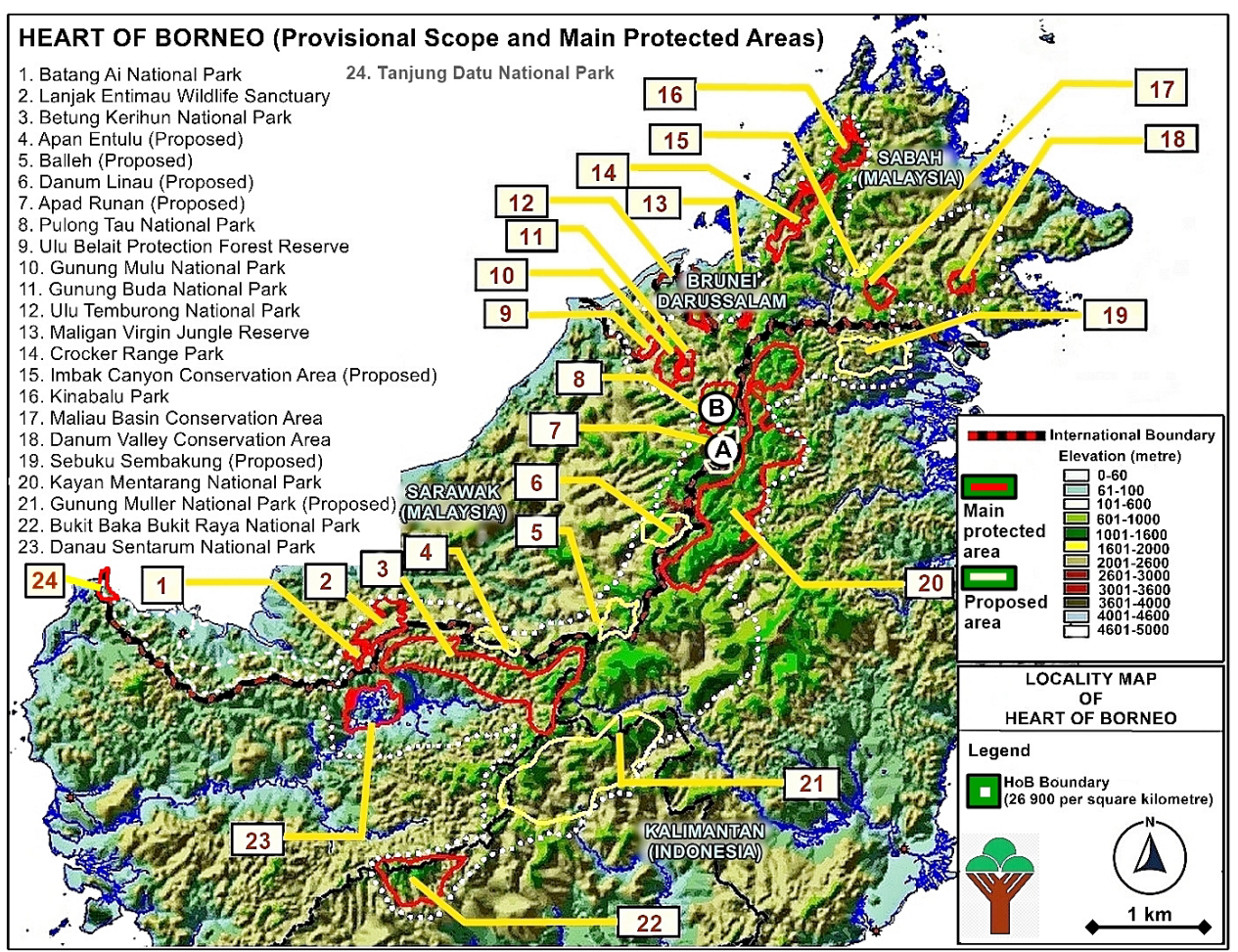

Fig. 1. The map of the Sarawak's Heart of Borneo Conservation belt. A: Long Banga; B: Tama Abu. Both areas are located in Baram district within Tama Abu range (Source: Sarawak Forest Department). 
Geographically, Long Banga and Tama Abu share comparatively similar vegetation types as in Bario highland and Pulong Tau, located in the Northeastern part of Sarawak, too (Beaman et al., 2001; Pearce, 2006). The Tama Abu Permanent Forest Reserve is located at the south-eastern part of Pulong Tau National Park, Ulu Baram, near the border with Indonesia. It is characterised mainly by over-logged forests and forests affected by shifting cultivation carried out by the indigenous people (Durst et al., 2005; Ling et al., 2019). Patches amidst inland forests are still in fairly good condition despite the past logging activities as shown by the emergence of many large trees (Ling et al., 2019). There is a highland plateau of over $1000 \mathrm{~m}$ a.s.1. The Long Banga and Tama Abu forests are comparable to Pulong Tau's, where the studied areas consist of mixed dipterocarp forest, alluvial and riverine, hill and lower montane vegetation types, except lacking or absence of upper montane and kerangas or tropical heath forests. The lower moisture and temperature were strongly influenced by both altitude and the presence of forest canopy (Pearce, 2006). Also, its permanently wet and rich mineral soil in the riverine, alluvial and mossy forests filled with humid air encourage mosses to grow on the trees makes the trees and ground a fitting habitat for orchids to root in (Wood \& Cribb, 1994; Pearce, 2006).

Specimens were processed according to the standard herbarium specimen preparation techniques outlined in Bridson \& Forman (2000) and stored in the Sarawak Herbarium (SAR), Forest Research Centre, Sarawak, Malaysia. Living specimens were processed according to Go et al. (2015). Some living collections were also made and brought back to the Research, Development, and Innovation Division (RDID) in Sarawak Forestry Department for propagation in the nursery. Reliable references were used in the identification and classification processes, including published accounts of Wood (1997, 2003), and Beaman et al. (2001). Currently accepted names of the orchids were checked using the KEW World Checklist of Selected Plant Families (WCSP) (Govaerts et al., 2020).

An assessment of the proposed conservation status was evaluated only for the endemic species. A guideline in IUCN Red List Categories and Criteria version 14 (August 2019) (IUCN Standards and Petitions Committee, 2019) was followed. The current information gathered on the endemic species are more applicable towards the assessment based on the geographical range in the form of the cur- rent Extent of Occurrence (EOO) and Area of Occupancy (AOO) of each species. The generalised information used in this study have been based on three main sources of information: (i) review of available literature, documents, and geo-referenced herbarium specimens; (ii) fieldwork in the accessible forests in Peninsular Malaysia and Borneo; (iii) personal and professional experience, including inference, suspicion, projection, and expert consultation. The range of distributions of each species was assessed using Geospatial Conservation Assessment Tool (GeoCAT) (http://geocat.kew.org/) (Bachman et al., 2011). The range of distribution from historical and current localities within Borneo was plotted in Google Earth maps. GeoCAT was also used to estimate the Extent of Occurrence (EOO) and Area of Occurrence (AOO) (Bachman et al., 2011). Extinction risk for each species was determined based on Criterion B (IUCN Standards and Petitions Committee, 2019). The current conservation status was checked using the IUCN Red List of Threatened Species database (http://www.iucnredlist.org).

Information on the current distribution status was retrieved from published checklists of Ridley (1896), Wood et al. (1993), Wood \& Cribb (1994), Chai (2000), Beaman et al. (2001), Pearce (2006), and Ling \& Sang (2018). The distribution was also referred to an orchid database of the Swiss Orchid Foundation (https://orchid.unibas.ch/index.php/en/), WCSP (Govaerts et al., 2020), and digitalised herbarium collections deposited in the National Herbarium of the Netherlands (NHN) accessed through Browse Dutch Natural History Collections: BioPortal (Naturalis) (http://bioportal. naturalis.nl/), Natural History Museum Specimen Collection (https://data.nhm.ac.uk/) and Singapore Herbarium Online Database (SING) (http://herbaria.plants.ox.ac.uk/bol/sing).

\section{Results and Discussion \\ Species abundance and diversity}

The research expeditions accumulated a total of 118 species and 46 genera from three trails and non-trails, and a total of 117 species and 46 genera were collected from nine pre-created trails and one non-trail in the hills to lower montane forest, in Long Banga and Tama Abu, respectively. In total, we collected 206 orchid species belonging to 59 genera from the two highland forests in the Tama Abu range. However, 43 species of them were identified only at genus level due to the lack of floral structures or flowers alcohol collections. The living plants 
were cultivated in the RDID's nursery to induce flowering prior to further identification, but only a few of them were blooming. Consequently, the identification of the incomplete specimens was made based on the diagnostic morphology of vegetative structures alone. The results of the two research expeditions are listed in Electronic Supplement 1 (see Fig. S1, Fig. S2, Fig. S3, Fig. S4) and Electronic Supplement 2.

The composition of orchid genera found in Tama Abu was very similar to data obtained in Long Banga, where Bulbophyllum, Dendrobium, and Coelogyne were the most abundant genera collected. The remaining genera were Agrostophyllum, Appendicula, Liparis, Oberonia, Phalaenopsis, Pinalia, Phaius, and Vanda (Fig. 2). The discovery of several Phalaenopsis species and a Vanda species in the Tama Abu forest astonished us, because these genera are recorded with a small distribution range and low occurrence in both Borneo and Peninsular Malaysia region.

\section{Species abundance based on subfamilies and growth habits}

The species composition is represented mostly by the Epidendroideae subfamily (198 species, 96.12\%) and the remaining subfamilies are Apostasioideae (two species, 0.97\%), Orchidoideae (five species, 2.43\%) and Vanilloideae (one species, $0.49 \%$ ), where this also reflects the high richness of epiphytes (176 species, 85.44\%) found during the expeditions in these two habitats. The remaining 23 species $(11.17 \%)$ were found as terrestrial plants, including five species of mycoheterotrophs $(2.43 \%)$ that obtain nutrients from mycorrhizal fungi (Fig. 3).

\section{Species abundance and diversity based on vegetation types}

In Long Banga, our field collection had yielded us with 63 orchid species from the riverine forests (Fig. 4). The inland area was more disturbed and gaps were apparent. The species diversity can be considered as high given the possibility that the area may have been overlogged. More orchids were found in the riverine forest compared to the inland montane forests in Long Banga owing to the less disturbed canopy and ground conditions. It is also assumed during the sample collection that in the riverine area these orchids were easily collected by hands, without the need for tools or to climb trees. Probably because of this, many epiphytic species were usually collected and documented (Ling $\&$ Sang, 2018). However, here we make another conclusion on it. In the riverine forest, the moisture level was equally ideal as in a primary inland forest as it was constantly moisturised by the flowing stream. The height of the riverine trees, where the orchids grew on, were of average size. Despite of that, the orchids were still in a high abundance. The deep shade provided by wide branching of the riverine trees has made the environment favourable for the moisture-lover plants, such as mosses and shade-loving orchids to grow in (O’Malley, 2009; Benítez et al., 2015). Likewise, the trees with widely spreading branches would equally have also exposed the sun-loving epiphytic orchids to the sunlight (Timsina et al., 2016). On these sites, the tree crowns are dense and banked by alluvial vegetation with a shallow peat layer which may never experience soil water deficits (Pearce, 2006). In addition, there was no evidence that in the riverine forest, the orchids are being negatively affected by flood, which implies a better chance of survival and pollination.

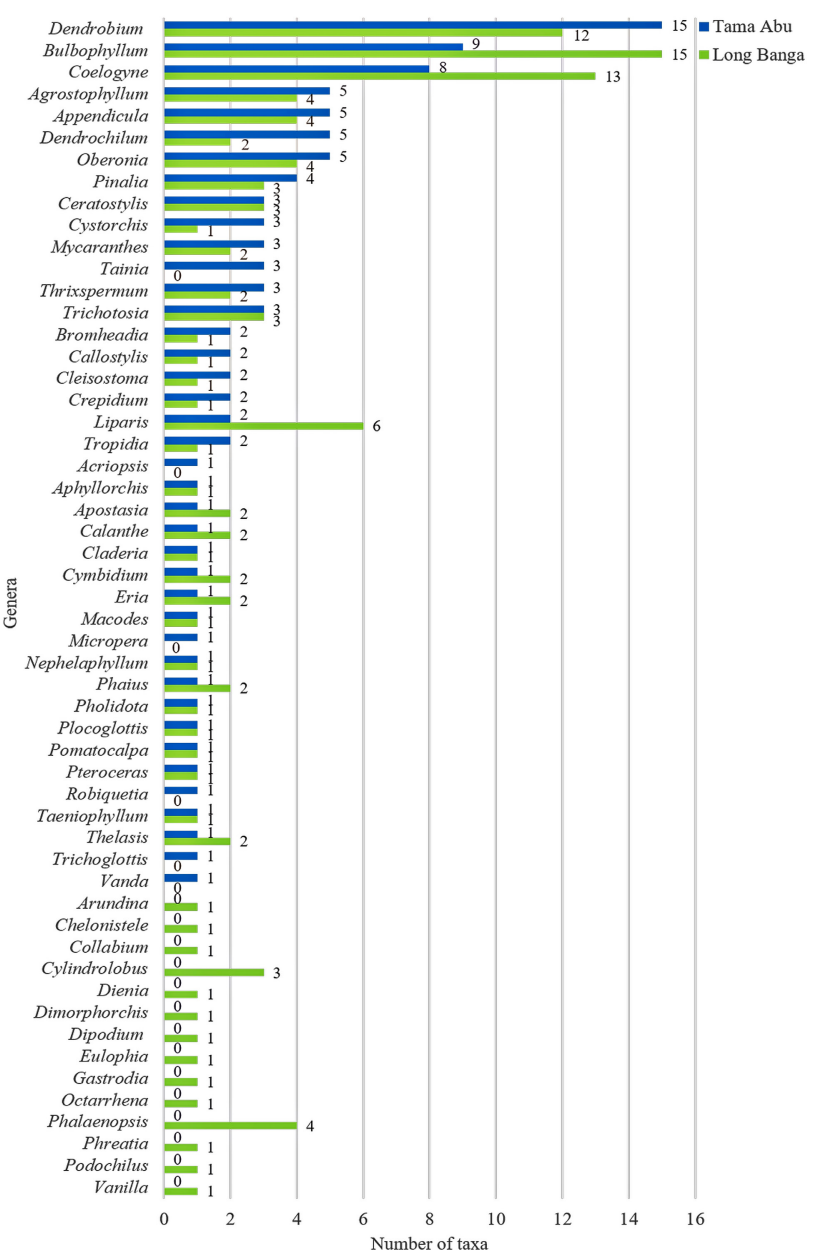

Fig. 2. Abundance of orchid taxa based on genera found in the highland forests of Long Banga and Tama Abu, Sarawak, Heart of Borneo. 


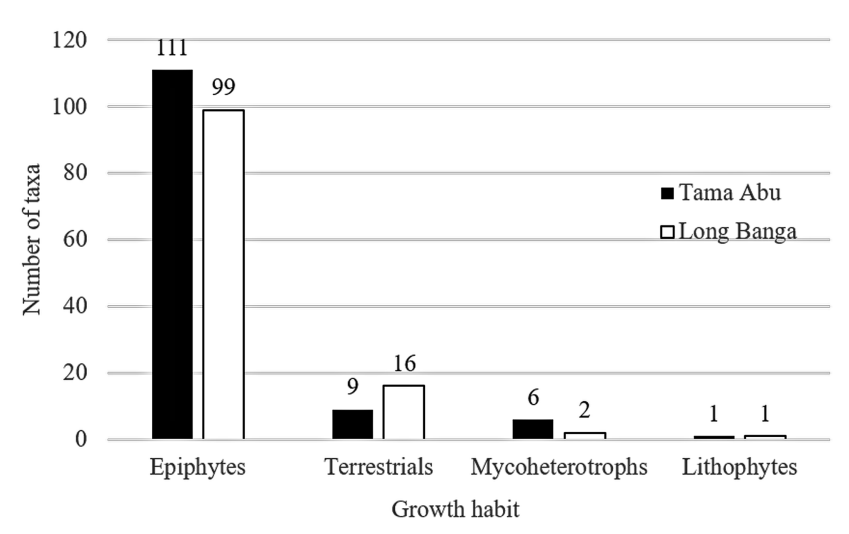

Fig. 3. Number of orchid taxa with different growth habits found in the highland forests of Long Banga and Tama Abu, Sarawak, Heart of Borneo.

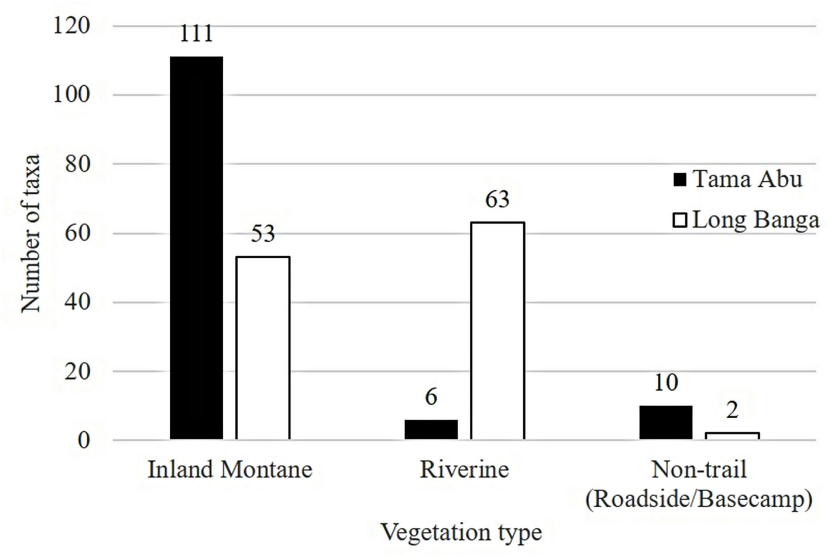

Fig. 4. Number of orchid taxa in different vegetation types in the highland forests of Long Banga and Tama Abu, Sarawak, Heart of Borneo.

Although the orchids were less abundant, the inland forest was still harbouring a great diversity of orchid species. It may probably be caused by the presence of large and varied types of host plants for epiphyte colonisation. It could be expected that shade-demanding species of Bulbophyllum, Dendrobium and Coelogyne would be in the highest abundance in canopy-protected forests with less direct exposure to the sun rays as favourable (Ling \& Sang, 2018; Besi et al., 2019b). These groups are mostly composed of highland orchid species with coriaceous or leathery leaves, with or without pseudobulbs, and adapted only to wet and cool conditions (Seidenfaden \& Wood, 1992; Wood et al., 1993; Besi et al., 2019b). Still, some vegetation patches were opened with wide canopy gaps. These canopy gaps may be caused by natural disturbance, including windfall, lightning strike, and death of an emergent individual trees from a pathogen (Ashton, 2008). In addition, it could be due to many pioneer and successional plant species, which increased in abundance following past logging in the area (Newman, 1990; Demies et al., 2019). However, our claim appears predictive, inferred from empirical observation during the exploration, though as yet we have no supporting evidence. Without the canopy protection, full sunlight and radiation reach and heat up the ground, altering the atmosphere and soil microclimatic stratifications (Werner \& Gradstein, 2009; Benítez et al., 2015; Besi et al., 2019b). Even slight differences in the humidity may be considerable for fragile plants that highly dependent on water and organic matters for survivability (Werner \& Gradstein, 2009). In addition, we predict that in the hill forest, the reduction of the continuous suitable habitat poses a serious ecological conundrum causing a remarkably low abundance of the orchid community.

In Tama Abu, on the contrary, a high abundance, and diversity of orchid species was harvested from the inland hills and montane forests with dense tree canopy and relatively undisturbed ground, including the terrestrial and mycoheterotroph orchids (Fig. 4). The constantly wet environment was not just affecting the ground condition, but also had promoted the growth of mosses on the trees and rocks. This reflects the high number of epiphytes encountered during expeditions (Wood et al., 1993; Wood \& Cribb, 1994; Benítez et al., 2015). The extensive stands of mature and large trees form an emergent layer with interlocked canopy that provide the shaded and well-watered sites for the terrestrial orchids. One more factor is the thick humus layer covering the moist ground, which certainly provides the nourishment to the terrestrial orchids, and the mycoheterotroph orchids relying on mycoheterotrophy at some point in their life cycle, especially at germination (Leake, 1994; Leake et al., 2004; Leake \& Cameron, 2010). These plants are inconspicuous and have an ephemeral lifestyle hidden from a plain sight. Their mycorrhizal symbiosis with both fungal partners and autotrophic plants depends much on the soil stratification (Martos et al., 2009; Leake \& Cameron, 2010). In addition, the lower montane mossy forest is an important habitat specialised with a specific vegetation structure and is relatively continuous. This specialised habitat is characterised by a high orchid endemism.

The riverine forest was populated by trees with small trunks and branches with layered and thicker crown rather than spreading. It makes them less favourable for epiphytes to grow on. Small trunks and branches reduce space for colonisation for epiphytic plants. In tropical forests, the distribution and abundance of epiphytic species depend on the different host characteristics (Hietz, 1999; Callaway et al., 2002; Partomihardjo et al., 2004; Adhikari et al., 2012; Hsu et al., 2014). 


\section{Rareness and endemism of orchids}

A known commercially important orchid taxon, Vanilla, is a genus that contributes to the Vanilla flavour in our daily foods (Raffi et al., 2017). Vanilla from Borneo is understudied due to a low number of collections from the field and infrequent flowering (Cribb, 2014; Ling \& Ong, 2016). Until now, only five species are recorded for Sarawak (Ling \& Ong, 2016). Vanilla was also found along with the terrestrial and «jewel» orchids, including Cystorchis javanica (Blume) Blume, Cystorchis stenoglossa Schltr., Cystorchis variegata Blume, and Macodes petola (Blume) Lindl. (Fig. S1). The rarely encountered mycoheterotroph orchids were equally found in Long Banga and Tama Abu, such as Aphyllorchis and Cystorchis (Fig. S1). An exception is three rarely encountered orchid species Bromheadia rupestris Ridl., Dendrobium tetrachromum Rchb.f., and Nephelaphyllum tenuiflorum Blume, found only in Tama Abu (Fig. S1).

Furthermore, we highlighted here the discovery of ten endemics, yet endangered orchid species in Borneo, including Calanthe crenulata J.J.Sm., Coelogyne endertii J.J.Sm., Dendrochilum pubescens L.O.Williams, Dimorphorchis lowii (Lindl.) Rolfe, Phalaenopsis modesta J.J.Sm., Pteroceras fragrans (Ridl.) Garay, Robiquetia transversisaccata (Ames \& C.Schweinf.) J.J.Wood, Tainia scapigera (Hook.f.) J.J.Sm., Trichotosia brevipedunculata (Ames \& C.Schweinf.) J.J.Wood, and Tropidia saprophytica J.J.Sm. (Fig. S2).

Conservation assessment of the endemic species

In Borneo, Orchidaceae is one of the top priority rescue families listed in the Wildlife Protection Ordinance, 1998 (Laws of Sarawak, 1998). However, there is no publication that could specifically pilot orchid conservation assessment neither in Borneo nor in Sarawak. About 10\% of the discovered orchid species, including endemics (Fig. 5), have a restricted distribution area. However, we found a group of incompletely identified species $(20 \%)$, which could harbour a higher number of endemic and rare species. The narrowly distributed and highland-confined species require large stands of forest for reproductive success. Now, these are facing extinction due to the loss of vital pollinators and genetic erosion (Cribb et al., 2003; Memmott et al., 2007). Thus, conservation of the specialised habitats with distinct floras, especially those rich in endemics, should then aim to legislate (Ashton, 2008).

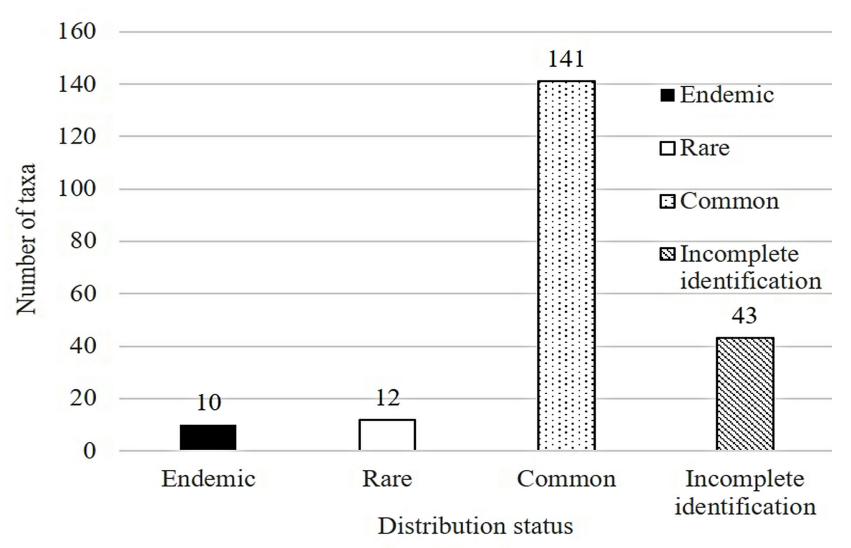

Fig. 5. Distribution status of orchids found in Long Banga and Tama Abu, Sarawak, Heart of Borneo.

Hence, we include our first result on the proposed conservation status assessment for the ten endemic species of Borneo found in Long Banga and Tama Abu, including data on their current distribution, AOO, and EOO values (Table). GeoCAT maps show their current extent of occurrence (Fig. 6).

Based on the current IUCN Red List of Threatened Species, only Tropidia saprophytica has been globally assessed for its conservation status. It is classified as Least Concern (Chadburn, 2014). This orchid species is rarely seen and easily unnoticed in the wild (Wood et al., 1993; Chan et al., 1994) because it is inconspicuous, and on the basis of its small size it has a brownish but light-coloured appearance that resembles the leaf litter and often secluded under the understory vegetation. This orchid was recorded in Protected Areas in Sarawak, Sabah and Brunei. However, such areas may still be exposed to anthropogenic and naturogenic disturbances (Chadburn, 2014). Our further survey on the population status, ecology and specific threats affecting $T$. saprophytica in the Tama Abu forest shows that now it is more correct to the threatened IUCN category rather than as Least Concern.

On the basis of the estimation of their proposed conservation status, we assessed the endemic species as Endangered taxa, EN B2b(iii) (Table), with estimated AOO is less than 500 $\mathrm{km}^{2}$ and continuing decline in extent and quality of habitat (IUCN Standards and Petitions Committee, 2019). The estimated EOOs exceed the thresholds needed for the threatened IUCN category, and the current collection locations are still situated within Protected Areas for some of these endemic species. However, all species occur within narrow AOOs in Bor- 
neo, in the hills and lower montane forests. In Borneo, the mentioned forest types are now facing rampant anthropogenic destructions, mainly logging for timber extraction (Wood et al., 1993; Ashton, 2008). Below we discuss the foreseen anthropogenic threats occurring around the forest margins in Long Banga and Tama Abu. Due to the rampant tree extraction activities, their at-risk habitats are qualified them as one of the most threatened. Also, in regard to the most vulnerable mycoheterotrophs orchids, their lacking of chlorophyll and normally developed leaves entails its high dependence on the ground or soil conditions (Leake \& Cameron, 2010; Campbell, 2014). In addition, it is not known to be conserved ex situ. In any case, this would be very difficult because of its dependence on soil fungi (Campbell, 2014; Chadburn, 2014).

The habitat reduction positively influences the species extinction rates. The removal of the forest fragments and host plants cause rapid population decline of the inhabitants (Gradstein, 2008). The habitat destruction may have gradually driven many orchid species close to extinction (Mondragon \& Calvo-Irabien, 2006). It is debatable whether assisted geographical and marginal migrations can overcome the disturbance even with the presence of their adaptive survival strategies in accordance with the environmental alterations caused by climate changes (Cribb et al., 2003).

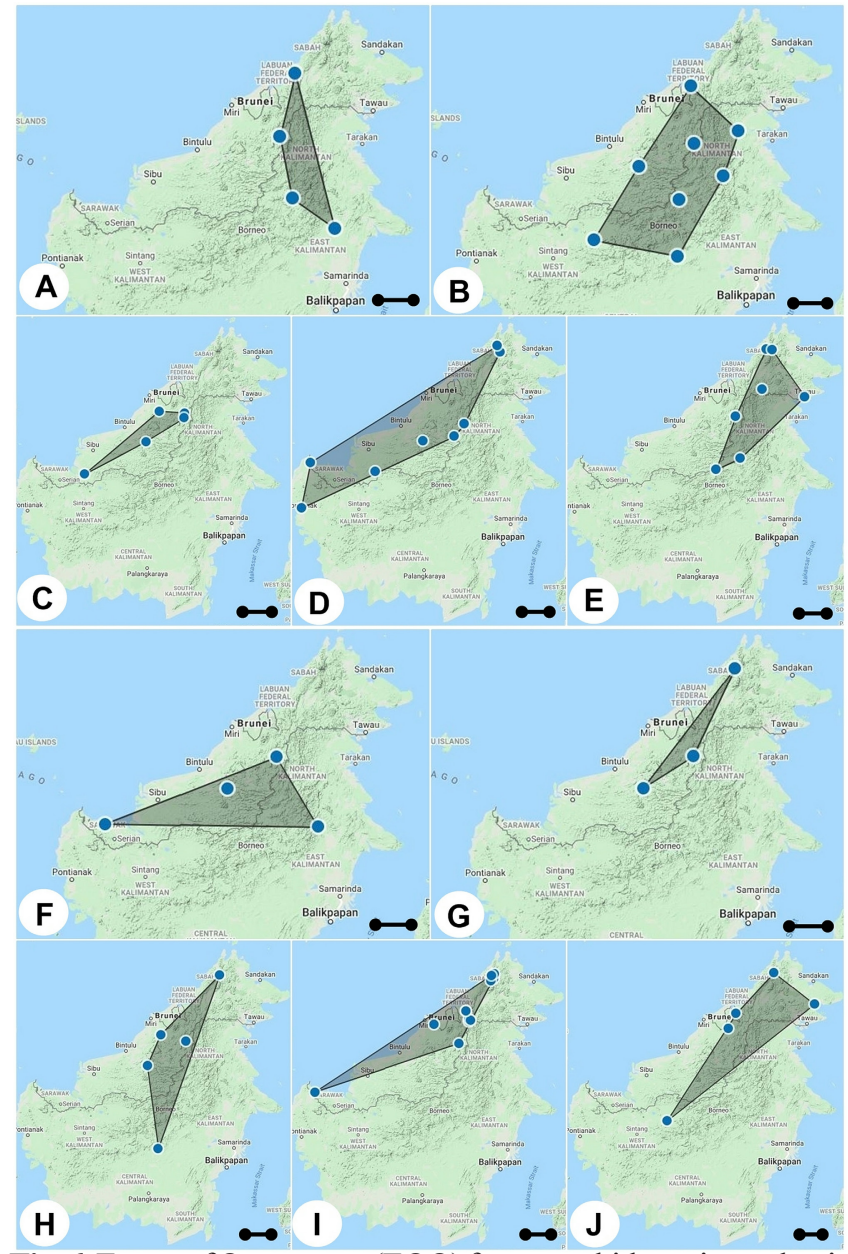

Fig. 6. Extent of Occurrence (EOO) for ten orchid species endemic in Borneo found in Long Banga and Tama Abu, Sarawak, Heart of Borneo. Designations: A) Calanthe crenulata; B) Coelogyne endertii; C) Dendrochilum pubescens; D) Dimorphorchis lowii; E) Phalaenopsis modesta; F) Pteroceras fragrans; G) Robiquetia transversisaccata; H) Tainia scapigera; I) Trichotosia brevipedunculata; J) Tropidia saprophytica. Scale bar: $2 \mathrm{~km}$.

Table. List of ten orchid species endemic in Borneo, found in Long Banga and Tama Abu, Sarawak, Heart of Borneo, and their conservation status

\begin{tabular}{|c|c|c|c|c|c|}
\hline No & Taxa & $\begin{array}{c}\text { Proposed } \\
\text { conservation status }\end{array}$ & Distribution & $\begin{array}{l}\text { Area of Occupancy } \\
(\mathrm{AOO}) / \mathrm{km}^{2}\end{array}$ & $\begin{array}{c}\text { Extent of Occurrence } \\
(\mathrm{EOO}) / \mathrm{km}^{2}\end{array}$ \\
\hline 1 & Calanthe crenulata J.J.Sm. & EN B2b(iii) & Kalimantan, Sabah, Sarawak & $16 \mathrm{~km}^{2}(\mathrm{EN})$ & $33028.043 \mathrm{~km}^{2}(\mathrm{NT})$ \\
\hline 2 & Coelogyne endertii J.J.Sm. & EN B2b(iii) & Brunei, Kalimantan, Sarawak & $32 \mathrm{~km}^{2}(\mathrm{EN})$ & $116225.306 \mathrm{~km}^{2}(\mathrm{LC})$ \\
\hline 3 & $\begin{array}{l}\text { Dendrochilum pubescens } \\
\text { L.O.Williams }\end{array}$ & EN B2b(iii) & Brunei, Sarawak & $20 \mathrm{~km}^{2}(\mathrm{EN})$ & $21883.777 \mathrm{~km}^{2}(\mathrm{NT})$ \\
\hline 4 & Dimorphorchis lowii (Lindl.) Rolfe & EN B2b(iii) & Kalimantan, Sabah, & $32 \mathrm{~km}^{2}(\mathrm{EN})$ & $164596.037 \mathrm{~km}^{2}(\mathrm{LC})$ \\
\hline 5 & Phalaenopsis modesta J.J.Sm. & EN B2b(iii) & Kalimantan, Sabah, Sarawak & $28 \mathrm{~km}^{2}(\mathrm{EN})$ & $71446.487 \mathrm{~km}^{2}(\mathrm{LC})$ \\
\hline 6 & Pteroceras fragrans (Ridl.) Garay & EN B2b(iii) & Kalimantan, Sarawak & $16 \mathrm{~km}^{2}(\mathrm{EN})$ & $76843.461 \mathrm{~km}^{2}(\mathrm{LC})$ \\
\hline 7 & $\begin{array}{l}\text { Robiquetia transversisaccata } \\
\text { (Ames \& C.Schweinf.) J.J.Wood }\end{array}$ & EN B2b(iii) & Sabah, Sarawak & $12 \mathrm{~km}^{2}(\mathrm{EN})$ & $15567.035 \mathrm{~km}^{2}(\mathrm{VU})$ \\
\hline 8 & Tainia scapigera (Hook.f.) J.J.Sm & EN B2b(iii) & Kalimantan, Sabah, Sarawak & $20 \mathrm{~km}^{2}(\mathrm{EN})$ & $70726.459 \mathrm{~km}^{2}(\mathrm{LC})$ \\
\hline 9 & $\begin{array}{l}\text { Trichotosia brevipedunculata } \\
\text { (Ames \& C.Schweinf.) J.J.Wood }\end{array}$ & EN B2b(iii) & Sabah, Sarawak & $52 \mathrm{~km}^{2}(\mathrm{EN})$ & $75049.280 \mathrm{~km}^{2}(\mathrm{LC})$ \\
\hline 10 & Tropidia saprophytica J.J.Sm. & EN B2b(iii) & $\begin{array}{l}\text { Brunei, Kalimantan, Sabah, } \\
\text { Sarawak }\end{array}$ & $20 \mathrm{~km}^{2}(\mathrm{EN})$ & $93229.863 \mathrm{~km}^{2}$ (LC) \\
\hline
\end{tabular}

Note: Conservation status based on $\mathrm{AOO}$ and EOO data obtained using the GeoCat, and included here in the last two columns on the right. Abbreviations: EN - Endangered, VU - Vulnerable, NT - Near Threatened, LC - Least Concern. 
For each of the threat category, the IUCN Red List has mainly quantitative thresholds (IUCN Standards and Petitions Committee, 2019). However, our study of conservation assessment is still inadequate. Data on AOO and EOO presented here (Table, Fig. 6) may probably underestimate due to the exclusion of doubtful specimens deposited in the local herbaria and specimens with insufficient data on the locality. The qualitative data will undoubtedly adjust upon further identification of specimens. Nonetheless, the system remains fairly adjustable to ensure that taxa, of which with very limited information is known, could also be assessed. To estimate the continuing decline in habitat area for $\mathrm{B} 2 \mathrm{~b}$ according to IUCN criteria, we incorporated inferences, suspicions, and projections to test a taxon. This was highly based on an empirical study carried out by the authors and on evaluation of attached notes on the available herbarium specimens. We cannot ignore the importance of these inferences, suspicions, and projections. Here, the partial but continuous biodiversity monitoring is useful and must be documented (IUCN Standards and Petitions Committee, 2019). For the endemic species found in Long Banga and Tama Abu areas, the proposed conservation status could provide information for the IUCN Red List categories and criteria assessments.

\section{Notes on records of orchids new to Borneo}

There are no comprehensive records published on orchids in the Tama Abu range. To date, minor data are available on the diversity of wild orchids in the surrounding areas represented by similar vegetation structures to Long Banga and Tama Abu forests and considerably the nearest ones: (i) the earliest record of orchids in Borneo first coined in Ridley (1896); (ii) a checklist of the orchids in Borneo including Kalimantan and Brunei (Wood \& Cribb, 1994); (iii) a checklist of flora, fauna, food and medicinal plants in the Lanjak Entimau Wildlife Sanctuary (Chai, 2000); (iv) records of orchids in the Kelabit highlands (Beaman et al., 2001); (v) a record on the flora of Pulong Tau National Park (Pearce, 2006); (vi) Orchidaceae diversity in Murum Dam, Belaga, Sarawak (Ling \& Sang, 2018). Until now, the mentioned records and checklists are of most reliable accounts to evaluate the abundance and distribution of each species collected in Northern Sarawak. Below we present the new orchid records, including brief information on their habit, locality, habitat, current distribution status, and specimens examined.
Dendrobium appendiculatum (Blume) Lindl. Growth habit: epiphyte (Fig. S3). Locality: Tama Abu. Habitat: Lowland mixed dipterocarp forest. Distribution status: Rare. It was previously recorded from Thailand, Peninsular Malaysia, Sumatra and Java. Specimen examined: Malaysia, Sarawak, Marudi, Tama Abu, ca. 800 m a.s.l., 20.08.2017, Besi, Nikong, Go, RG5711 (SAR!); Indonesia, Java, unknown altitude, 1936, Blume, L0061248, digitalised specimen! (holotype NHN); Indonesia, Java, Sukabumi, unknown altitude, 31.01.1912, Schoggers, L0063899, digitalised specimen! (syntype NHN).

Phaius indigoferus Hassk. Growth habit: terrestrial or lithophyte (Fig. S3). Locality: Tama Abu. Habitat: Hills to montane forests. Distribution status: Rare in Peninsular Malaysia. It was previously recorded from Thailand, Java and Peninsular Malaysia (Terengganu) (Besi et al., 2019a). Specimen examined: Malaysia, Sarawak, Marudi, Tama Abu, ca. 600 m a.s.1., 18.08.2017, Besi, Nikong, Go, RG5643 (SAR!); Indonesia, Java, Sallak, unknown altitude, unknown date of collection, Kuhl \& Hasselt, L0061869, digitalised specimen! (syntype $\mathrm{NHN}$ ); Malaysia, Terengganu, Besut, ca. 500 m a.s.1., 04.05.2018, Besi, Nikong, Go, EDW049 (UPM!).

\section{Conclusions}

The generalised records obtained from the two expeditions in the northeast region of Sarawak's Heart of Borneo strengthens the idea that the Sarawak's highland forest harbours a vast variety of orchid species. A total of 206 species and 59 genera were collected from the inland montane and riverine forests, as well as non-trail sites in Long Banga and Tama Abu forests. Bulbophyllum, Dendrobium, and Coelogyne were the genera with the highest number of species. Most of the documented species were epiphytes, including ten endemics and threatened species, as well as two species newly recorded for Borneo. Here, we emphasise the importance and influence of each vegetation type on the species abundance, where the highest diversity was found in the inland montane forests. In the inland montane forests, undisturbed sites were dominated by emergent trees with dense and spreading crown structure providing moisture that is suitable for both epiphyte and terrestrial plant colonisation. However, an even higher diversity of orchids could be expected, if all found specimens were fertile. Therefore, further cultivation of the living plants in an arboretum or an ex situ conservation prior to species identification is undoubtedly important. 


\section{Acknowledgments}

We would like to extend our appreciation to Sarawak Forestry Department for the invitation and the support us by the logistics, transportations, meals, and guides. We are grateful to UPM-KRIBB Project No. 6384300 and UPM Putra Grant No. 9413603 for supporting this research. A special gratitude to UPM and Ministry of Higher Education Malaysia (MOHE) for sponsoring this Doctorate Degree undertaking. Special thanks to the Ketua Kampung and his people upon their blessing and great support during the expedition. We would not be able to successfully explore the forest with these encouraging findings without their experience and skills.

\section{Supporting Information}

Photographs of selected orchid species known in Tama Abu and Long Banga, Heart of Borneo (Electronic Supplement 1: Orchid species found in Tama Abu and Long Banga, Sarawak, Heart of Borneo), and a detailed distribution of orchids in the study area (Electronic Supplement 2: List of orchid species found in the highland forests in Long Banga and Tama Abu, Heart of Borneo, including information on the growth habits and localities) may be found in the Supporting Information here.

\section{References}

Adhikari Y.P., Fischer H.S., Fischer A. 2012. Host tree utilization by epiphytic orchids in different land-use intensities in Kathmandu Valley, Nepal. Plant Ecology 213(9): 1393-1412. DOI: $10.1007 / \mathrm{s} 11258-012-0099-0$

Ashton P.S. 2008. Changing values of Malaysian forests: the challenge of biodiversity and its sustainable management. Journal of Tropical Forest Science 20(4): 282-291.

Bachman S., Moat J., Hill A.W., de la Torre J., Scott B. 2011. Supporting Red List threat assessments with GeoCAT: geospatial conservation assessment tool. ZooKeys 150: 117-126. DOI: 10.3897/zookeys.150.2109

Beaman T.E., Wood J.J., Beaman R.S., Beaman J.H. 2001. Orchids of Sarawak. Kota Kinabalu: Natural History Publication. 548 p.

Benítez Á., Prieto M., Aragón G. 2015. Large trees and dense canopies: key factors for maintaining high epiphytic diversity on trunk bases (bryophytes and lichens) in tropical montane forests. Forestry 88(5): 521-527. DOI: 10.1093/forestry/cpv022

Besi E.E., Dome N., Mustafa M., Go R. 2019a. New records for orchids in Terengganu and Kelantan, Malaysia. Journal of Sustainability Science and Management 2: 1-25.

Besi E.E., Nikong D., Mustafa M., Go R. 2019b. Orchid diversity in antropogenic-induced degraded tropical rainforest, an extrapolation towards conservation. Lankesteriana 19(2): 107-124. DOI: 10.15517/ LANK.V19I2.38775

Bridson D., Forman L. 2000. The herbarium handbook. $3^{\text {rd }}$ ed. Kew: Royal Botanic Gardens. 348 p.
Callaway R.M., Reinhart K.O., Moore G.W., Moore D.J., Pennings S.C. 2002. Epiphyte host preferences and host traits: mechanisms for species-specific interactions. Oecologia 132(2): 221-230. DOI: 10.1007/s00442-002-0943-3

Campbell F. 2014. A summary of Holomycotrophic orchids. MIOS Journal 15(4): 6-17.

Chadburn H. 2014. Tropidia saprophytica. In: The IUCN Red List of Threatened Species 2014: e.T22486343A22487194. Available from https:// dx.doi.org/10.2305/IUCN.UK.2014-1.RLTS. T22486343A22487194.en

Chai P. 2000. Lanjak Entimau Wildlife Sanctuary: A Checklist of Flora, Fauna, Food and Medicinal Plants. Sarawak: Sarawak Forest Department and Yokohama. 217 p.

Chan C.L., Lamb A., Shim P.S., Wood J.J. 1994. Orchids of Borneo. Vol. 1: Introduction and a selection of species. Kota Kinabalu: The Sabah Society; Kew: The Royal Botanic Gardens. 402 p.

Cribb P.J. 2014. A synopsis of Vanilla in Borneo. Malesian Orchid Journal 13: 101-112.

Cribb P.J., Kell S.P., Dixon K.W., Barrett R.L. 2003. Orchid Conservation: a global perspective. In: K.W. Dixon, S.P. Kell, R.L. Barrett, P.J. Cribb (Eds.): Orchid Conservation. Kota Kinabalu: Natural History Publications (Borneo). P. 1-24.

Cruz-Fernández Q.T., Alquicira-Arteaga M.L., Flores-Palacios A. 2011. Is orchid species richness and abundance related to the conservation status of oak forest? Plant Ecology 212 (7): 1091-1099. DOI: 10.1007/s11258-010-9889-4

Demies M. Samejima H., Sayok A.K., Noweg G.T. 2019. Tree diversity, forest structure and species composition in a logged-over mixed dipterocarp forest, Bintulu, Sarawak, Malaysia. Transactions on Science and Technology 6(1-2): 102-110.

Durst P.B., Brown C., Tacio H.H., Ishikawa M. (Eds.). 2005. In Search of Excellence: Exemplary Forest Management in Asia and the Pacific. Bangkok: FAO. 418 p.

Edwards D.P., Woodcock P., Edwards F.A., Larsen T.H., Hsu W.W., Benedick S., Wilcove D.S. 2012. Reduced-impact logging and biodiversity conservation: a case study from Borneo. Ecological Applications 22(2): 561-571. DOI: $10.1890 / 11-1362.1$

Flores-Palacios A., Valencia-Díaz S. 2007. Local illegal trade reveals unknown diversity and involves a high species richness of wild vascular epiphytes. Biological Conservation 136(3): 372-387. DOI: 10.1016/j.biocon.2006.12.017

Gaveau D.L., Sloan S., Molidena E., Yaen H., Sheil D., Abram N.K., Ancrenaz M., Nasi R., Quinones M., Wielaard N., Meijaard E. 2014. Four decades of forest persistence, clearance and logging on Borneo. PLoS ONE 9(7): e101654. DOI: 10.1371/journal.pone.0101654

Go R., Pungga R.S. 2018. Sarawak Limestone Forests Orchids. Kuala Lumpur: University Putra Malaysia Press. 214 p.

Go R., Yong W.S.Y., Unggang J., Ridzuan S. 2010. Orchids of Perlis, jewels of the forest (Revised Edition). Perlis: Jabatan Perhutanan Perlis; Kuala Lumpur: Universiti Putra Malaysia. 152 p. 
Go R., Tan M.C., Naruddin A.A., Abdullah J.O., Ng Y.J., Nordin F.A., Khor H.E., Nulit R. 2015. Extinction risks and conservation status of Corybas (Orchidaceae; Orchidoideae; Diurideae) in Peninsular Malaysia. Phytotaxa 233(3): 273-280. DOI: 10.11646/phytotaxa.233.3.4

Gogoi K., Borah R.L., Das R., Yonzone R. 2012. Present Status of Orchid Species Diversity Resources of Joypur Reserve Forest of Dibrugarh District (Assam) of North East India. International Journal of Modern Botany 2(3): 47-67. DOI: 10.5923/j.ijmb.20120203.03

Govaerts R., Bernet P., Kratochvil K., Gerlach G., Carr G., Alrich P., Pridgeon A.M., Pfahl J., Campacci M.A., Baptista D.H., Tigges H., Shaw J., Cribb P., George A., Kreuz K., Wood J.J. 2020. World Checklist of Orchidaceae. Kew: Kew Royal Botanic Gardens. Available from http://apps.kew.org/wcsp/

Gradstein S.R. 2008. Epiphytes of tropical montane forestsimpact of deforestation and climate change. In: S.R. Gradstein, J. Homeier, D. Gansert (Eds.): The Tropical Mountain Forest - Patterns and Processes in a Biodiversity Hotspot. Biodiversity and Ecology Series. Book 2. Göttingen: Göttingen Centre for Biodiversity and Ecology. P: 51-65.

Haile N.S. 1962. The Geology and Mineral Resources of the Suai-Baram Area, North Sarawak. Kuching: Geological Survey Department, British Territories in Borneo. 176 p.

Hassler M., Rheinheimer J. 2013. Illustrated World Compendium of Orchids. List of Taxa. Available from https:// worldplants.webarchiv.kit.edu/orchids/

Hietz P. 1999. Diversity and conservation of epiphytes in a changing environment. Pure and Applied Chemistry 70(11): 1-11.

Hsu R.C.C., Wolf J.H., Tamis W.L. 2014. Regional and elevational patterns in vascular epiphyte richness on an East Asian island. Biotropica 46(5): 549-555. DOI: 10.1111/btp. 12131

IUCN Standards and Petitions Committee. 2019. Guidelines for Using the IUCN Red List Categories and Criteria. Version 14. Prepared by the Standards and Petitions Committee. Available from http://www.iucnredlist.org/ documents/RedListGuidelines.pdf

Lamb A. 1991. Orchids of Sabah and Sarawak. In: R. Kiew (Ed.): The state of nature conservation in Malaysia. Kuala Lumpur: Malayan Nature Society. P. 78-88.

Laws of Sarawak. 1998. Wildlife Protection Ordinance 1998. Kuala Lumpur: Percetakan Nasional Malaysia Berhad. Chapter 26. 33 p.

Leake J.R. 1994. The biology of myco-heterotrophic ('saprophytic') plants. New Phytologist 127(2): 171-216. DOI: 10.1111/j.1469-8137.1994.tb04272.x

Leake J.R., Cameron D.D. 2010. Physiological ecology of mycoheterotrophy. New Phytologist 185(3): 601-605. DOI: $10.1111 /$ j.1469-8137.2009.03153.x

Leake J.R., McKendrick S.L., Bidartondo M.I., Read D.J. 2004. Symbiotic germination and development of the myco-heterotroph Monotropa hypopitys in nature and its requirement for locally distributed Tricholoma spp. New Phytologist 163(2): 405-423. DOI: 10.1111/j.14698137.2004.01115.x
Liechti P., Roe F.W., Haile N.S. 1960. The Geology of Sarawak, Brunei and the Western Part of North Borneo. Kuching Sarawak: Geological Survey Department British Territories in Borneo. 360 p.

Ling C.Y., Ong P.T. 2016. Two new records of Vanilla for Sarawak. Malesian Orchid Journal 18: 79-84.

Ling C.Y., Sang J. 2018. Diversity of Orchidaceae from Murum Dam, Belaga, Sarawak, Borneo. Sibbaldia 16: 67-85.

Ling C.Y., Tsukaya H., Mustapeng A.M.A. 2019. Mycoheterotrophic plants of Tama Abu Protected Forest, Ulu Baram, Sarawak. Transactions on Science and Technology 6(1-2): 119-126.

Majit H.F., Lamb A., Miadin R., Suleiman M. 2014. The wild orchids of Crocker Range National Park, Sabah, Malaysia. Malayan Nature Journal 66(4): 440-462.

Martos F., Dulormne M., Pailler T., Bonfante P., Faccio A., Fournel J., Dubois M.P., Selosse M.A. 2009. Independent recruitment of saprotrophic fungi as mycorrhizal partners by tropical achlorophyllous orchids. New Phytologist 184(3): 668-681. DOI: 10.1111/j.14698137.2009.02987.x

Memmott J., Craze P.G., Nickolas M.W., Price M.V. 2007. Global warming and the disruption of plant-pollinator interactions. Ecology Letters 10(8): 710-717. DOI: 10.1111/j.1461-0248.2007.01061.x

Mondragon D., Calvo-Irabien L.M. 2006. Seed Dispersal and Germination of the epiphyte Tillandsia brachycaulos (Bromeliaceae) in a Tropical Dry Forest, Mexico. The Southwestern Naturalist 51(4): 462-470. DOI: 10.1894/0038-4909(2006)51[462:SDAGOT]2.0.CO;2

Newman A. 1990. Tropical Rainforest. A world survey of our most valuable and endangered habitat with a blueprint for its survival. New York USA: Facts on File, Inc. 256 p.

O’Malley K. 2009. Patterns of abundance and diversity in epiphytic orchids on Parashorea malaanonan trees in Danum Valley, Sabah. Plymouth Student Scientist 2(2): 38-58.

Ong P.T., O’Bryne P., Saw L.G., Chung R.C.K. 2017. Checklist of Orchids of Peninsular Malaysia. Kuala Lumpur: Perpustakaan Negara Malaysia. 169 p.

Partomihardjo T., Eizi S., Junichi Y. 2004. Development and distribution of vascular epiphytes communities on the Krakatau Islands, Indonesia. South Pacific Studies 25(1): 7-26.

Pearce K.G. 2006. The flora of Pulong Tau National Park. Sarawak: Sarawak Forest Department and Yokohama: International Tropical Timber Organization. 201 p.

Pridgeon A.M. 2014. Introduction. In: M. Gregory, D.F. Culter (Eds.): Orchidaceae - Anatomy of the Monocotyledons. Vol. X. UK: Oxford University Press. P. 1-43.

Raffi A., Abdullah N.A.P., Abdullah T.L., Go R. 2017. A new Vanilla species from Peninsular Malaysia. Malayan $\mathrm{Na}$ ture Journal 69(2): 17-22.

Ridley H.N. 1896. An enumeration of all Orchideae hitherto recorded from Borneo. Botanical Journal of the Linnean Society 31(215): 261-306. DOI: 10.1111/j.10958339.1896.tb00808.x 
Seidenfaden G., Wood J.J. 1992. The orchids of Peninsular Malaysia and Singapore. Kew: Royal Botanic Garden. 779 p.

Thomson G. 2015. Geology and Mineral Resources of Bario Area, Miri, Sarawak Malaysia. In: Rancangan Malaysia Kesepuluh, Projek Pemetaan Geologi Negara. Sarawak: Jabatan Mineral dan Geosains Malaysia. Explanation of Sheet 7220. No. Laporan: JMG.SWK (PGN) 2/2015.

Timsina B., Rokaya M.B., Münzbergová Z., Kindlmann P., Shrestha B., Bhattarai B., Raskoti B.B. 2016. Diversity, distribution and host-species associations of epiphytic orchids in Nepal. Biodiversity and Conservation 25(13): 2803-2819. DOI: 10.1007/s10531-016-1205-8
Werner F.A., Gradstein S.R. 2009. Diversity of dry forest epiphytes along a gradient of human disturbance in the tropical Andes. Journal of Vegetation Science 20(1): 59-68. DOI: 10.1111/j.1654-1103.2009.05286.x

Wood J.J. 1997. Orchids of Borneo. Vol. 3: Dendrobium, Dendrochilum and others. Kew: Royal Botanical Gardens. 299 p.

Wood J.J. 2003. Orchids of Borneo. Vol. 4. Kota Kinabalu: The Sabah Society; Kew: Royal Botanic Gardens. 314 p.

Wood J.J, Cribb P.J. 1994. A checklist of the Orchids of Borneo. Kew: Royal Botanical Gardens. 409 p.

Wood J.J., Beaman R.S., Beaman J.H. 1993. The Plants of Mount Kinabalu. Vol. 2: Orchids. Kew: Royal Botanic Gardens. 411 p.

\title{
РАЗНООБРАЗИЕ ДИКОРАСТУЩИХ ОРХИДЕЙ ВЫСОКОГОРНЫХ ЛЕСОВ «СЕРДЦА БОРНЕО»: ЛОНГ БАНГА И ТАМА АБУ (САРАВАК)
}

\author{
Э. Э. Беси ${ }^{1}$, Д. Никонг², Р. С. Пунгга ${ }^{3}$, Р. Го ${ }^{1, *}$ \\ ${ }^{1}$ Университет Путра Малайзии, Малайзия \\ ${ }^{2}$ Кг Сунгай Тонг, Теренгану, Малайзия \\ ${ }^{3}$ Департамент лесного хозяйства Саравака, Малайзия \\ *e-mail: rusea@upm.edu.my
}

Целью научных экспедиций в «Сердце Борнео», проведенных в Лонг Банге и Тама Абу, была документация высокогорных видов орхидей, обитающих в одном из крупнейших оставшихся пограничных тропических лесов в мире, площадь которых стремительно сокращается. В связи с этим может быть подготовлена резолюция о сохранении этих видов in situ и ex situ. Исследовательские экспедиции на охраняемых лесных участках позволили выявить 206 видов из 59 родов. В ходе экспедиции 2016 г. в Лонг Банге «Сердца Борнео» было обнаружено 118 видов из 46 родов, тогда как в ходе экспедиции 2017 г. в Тама Абу «Сердца Борнео» - 117 видов из 46 родов. Из них примерно 70\% видов относятся к эпифитам. Из них несколько видов (Aphyllorchis pallida, Cystorchis aphylla, Tropidia saprophytica) были микогетерофитами, а также некоторые являются «жемчужиной» тропиков, в т.ч. Cystorchis stenoglossa и Macodes petola. Неожиданно мы обнаружили ряд эндемичных и недавно зарегистрированных видов орхидей Борнео. В Лонг Банге приречные леса являются домом для большего количества орхидей, чем отмечено во внутренних лесах из-за присутствия деревьев-хозяев с раскидистой кроной и увлажненной текстурой коры, подходящей для колонизации эпифитов. Кроме того, приречные леса, окруженные заболоченной аллювиальной растительностью, благоприятно влияют на прорастание наземных видов орхидных. Участки внутренних лесов были нарушены с широкими просветами в лесном пологе, лишенном яруса возобновляющейся древесной растительности. Напротив, в Тама Абу внутренние леса оказались более предпочтительной средой обитания для орхидей, поскольку этот участок включает пояс ненарушенных лесов. Кроме того, они характеризовались более высокой влажностью, необходимой для роста орхидей. Неудивительно, что большое количество видов орхидей было обнаружено в ненарушенном внутреннем холмистом лесу с высокой сомкнутостью лесного покрова. Наблюдался переход от холмистых лесов к горной растительности с меньшим количеством видов орхидей. Этот параметр достигает максимума на участке мшистых лесов, особой среды обитания, в которой обитают эндемичные и редкие виды. Кроме того, десять эндемичных видов были оценены с категорией МСОП EN B2b(iii). При этом мы делаем вывод о необходимости постоянного мониторинга и оценки сохранения биоразнообразия для гарантии выживания видов орхидей и выявления точного видового богатства в высокогорных местообитаниях Саравака. Кроме того, здесь подчеркивается необходимость создания дендрария или центра сохранения орхидей для проведения ботанических исследований.

Ключевые слова: Orchidaceae, видовой состав, внутренний лес, Малайзия, оценка охраны, приречный лес, Северный Саравак, эндемизм 